\title{
Research of Loading of Structural Bonds Created with One-Component Epoxy Adhesives
}

Miroslav Müller, Jan Cidlina

Faculty of Engineering, Czech University of Life Sciences Prague. Czech Republic. E-mail: muller@tf.czu.cz, cidlina@tf.czu.cz.

An adhesive bonding technology is a method of a connecting which is used at a construction of coach-works, agricultural machines etc. This method is suitable for workings with a serial production. Many research projects dealt with a preparation of adhesive bonds, degradation aspects etc. An area, which has not been properly investigated at present, is an influence of a loading speed on strength of the adhesive bond and a destruction time of the adhesive bond. Adhesive bonds are loaded by a different intensity and a speed at a practice.

The research focused on an evaluation of the influence of the loading speed at a temperature $22 \pm 2{ }^{\circ} \mathrm{C}$ on the shear tensile strength, the time needed for the destruction and a failure area. Second part of the research was focused on the influence of a bending moment. This bending moment can be minimalized by using so-called underlaying sheet of metal. The underlaying sheet of metal was of a thickness corresponding to a thickness of the adhesive bonded material. Also a behaviour of the adhesive bonded material was observed within the research.

Keywords: Adhesive bond, bending moment, loading speed, time

\section{Acknowledgement}

This paper has been done when solving the grant IGA TF (No.: 2014:31140/1312/3133).

\section{References}

[1] MÜLLER, M., HERÁK, D. (2010). Dimensioning of the bonded lap joint. In: Research in Agricultural Engineering, Vol. 2, pp. 59-68.

[2] MÜLLER, M. (2013). Research of renovation possibility of machine tools damage by adhesive bonding technology. In: Manufacturing Technology, Vol. 4, pp. 504-509.

[3] MÜLLER, M. (2013). Research of liquid contaminants influence on adhesive bond strength applied in agricultural machine construction. In: Agronomy Research, Vol. 1, pp.147-154

[4] MÜLLER, M., VALÁŠEK, P. (2014). Environmental degradation aspects influencing coach-working one-component epoxy adhesives. In: Research in Agricultural Engineering, Vol. 1, pp. 37-43.

[5] SURESH, N., NEWAZ, G., PATTERSON, C. (2000). Effect of temperature and loading rate on adhesively bonded fiber reinforced plastic automotive sections, In: SAE Technical Papers.

[6] RUDAWSKA, A. (2014). Selected aspects of the effect of mechanical treatment on surface roughness and adhesive joint strength of steel sheets. In: International Journal of Adhesion and Adhesives, Vol. 50, pp. 235-243.

[7] MESSLER, R., W. (2004). Joining of materials and structures from pragmatic process to enabling technology. Burlington: Elsevier, 816 pp.

[8] HABENICHT, G. (2002). Kleben: Gundlagen, Technologien, Anwendung. Berlin: Springer. 921 pp.

[9] GRANT, L. D. R., ADAMS, R.D, DA SILVA, L.F.M (2009). Experimental and numerical analysis of single-lap joints for the automotive industry. In: International Journal of Adhesion \& Adhesives, Vol. 4, pp. 405-413.

[10] ADAMS, R. D., COMYN, J., WAKE, W. C. (1997). Structural adhesive joints in engineering. 2nd ed. Chapman \& Hall, London. 360 pp.

[11] LANG, T. P., MALLICK, P. K. (1999). The effect of recessing on the stresses in adhesively bonded single-lap joints. In: International Journal of Adhesion \& Adhesives, Vol. 4. pp. 257-271.

[12] FESSEL, G., BROUGHTON, J. G., FELLOW, N. A., DURODOLA, J. F., HUTCHINSON, A. R. (2007). Evaluation of different lap-shear joint geometries for automotive applications. In: International Journal of Adhesion \& Adhesives, Vol. 7, pp. 574-583.

[13] NOVÁK, M. (2011). Surface duality hardened steels after grinding. In: Manufacturing technology, Vol. 11, pp $55-59$.

[14] HOLEŠOVSKÝ, F., NÁPRSTKOVÁ, N., NOVÁK, M. (2012). GICS for grinding process optimization. In: Manufacturing technology, Vol. 12, pp. 22-26. 
[15] KROLCZYK, G., LEGUTKO, S. (2013). The machinability of duplex stainless steel-solutions in practice. In: Manufacturing technology, Vol. 13, pp. 473-478.

[16] HOLEŠOVSKÝ, F., NOVÁK, M., LATTER, M., VYSLOUZIL, T. (2013). Machining and its influence to surface quality of machine parts. In: Key Engineering Materials. Vol. 581. pp. 354-359.

[17] JÓZWIK, J., KURIC, I., SÁGA, M., LONKOWIC, P. (2014). Diagnostics of CNC machine tools in manufacturing process with laser interferometer technology. In: Manufacturing technology, Vol. 14, pp. 23-30.

[18] KARAC, A., BLACKMAN, B. R. K., COOPER, V., KINLOCH, A. J., RODRIGUEZ SANCHEZ, S., TEO, W. S., IVANKOVIC, A. (2011). Modeling the fracture behaviour of adhesively-bonded joints as a function of test rate. In: Engineering Fracture Mechanics, Vol. 78, pp. 973-989.

[19] MÜLLER, M., CHOTĚBORSKÝ, R., VALÁŠEK, P., HLOCH, S. (2013). Unusual possibility of wear resistance increase research in sphere of soil cultivation. In: Tehnicki Vjesnik-Technical Gazette, Vol. 4, pp. 641-646.

Copyright (C) 2015. Published by Manufacturing Technology. All rights reserved. 